\title{
Online Learning Engagement Model for International Students in Indonesia amid Covid-19 Period: A Conceptual Model Proposal
}

\author{
Mussa Saidi Abubakari \\ Faculty of Engineering, Graduate School, Universitas Negeri Yogyakarta, \\ Yogyakarta, Indonesia \\ abu.mussaside@gmail.com \\ Mashoedah \\ Faculty of Engineering, Graduate School, Universitas Negeri Yogyakarta, \\ Yogyakarta, Indonesia \\ mashoedah@uny.ac.id
}

\begin{abstract}
Universities in Indonesia implemented online learning following the command by the government as among the ways to mitigate the Covid-19 infections. However, fully online learning is a new experience for most educators and students including international students in Indonesia. Little is known about factors influencing online learning engagement, particularly in relation to international students. Therefore, this study proposes a conceptual model of online learning engagement based on literature review. Thus, method used is reviewing previous studies obtained from various academic journals which discussed the concept of student engagement and its related factors. The results of literature analysis indicate that student engagement is a crucial factor towards student academic and nonacademic success. Also, findings from analysis indicate that, learner engagement is influenced by a number of factors such as institutional support, instructor interactivity, student motivation, and learning material interactivity. Finally, the conceptual model of online learning engagement is proposed based on previous empirical studies. Recommendation for future studies is also discussed.
\end{abstract}

Keywords: COVID-19, Indonesia, International students, Motivation, Online learning, Student engagement.

\section{Introduction}

Recently, the deadly disease caused by corona virus (COVID-19) has been a hot topic of conversation. In most hemispheres of the world, corona still dominates public space. Within few months the virus spread very quickly and has touched almost all countries, including Indonesia, after it was first detected at the end of December 2019 in Wuhan city, China. Hence, amid March, 2020 the World Health Organization (WHO) announced the disease as the world pandemic (WHO, 2020b, 2020a; World Health Organization, 2020; Ying et al., 2020). This phenomenon has necessitated individuals to redefine their life purpose, humanity nature, and the goals of learning. Humans are forced to change their daily routines, to make sense of what they are actually looking for in life. The current pandemic has an impact on all social-economic sectors such as the world of education, including higher education. Many governments including Indonesia, have implemented a social or physical distancing policy to minimize the spread of Covid-19 in their communities. The Indonesian Ministry of Education and Culture responded with a policy of teaching and studying from home. The existence of this virus outbreak hinders teaching and 
learning activities that usually take place in face-to-face environment. Even so, this pandemic was able to accelerate education 4.0. The learning system is carried out remotely by utilizing information and communications technologies (ICT).

Indonesia like many other countries, is also facing a big challenge in handling Covid-19. Among the aspects that are currently challenging, educational aspect is also essential for discussion. Despite the corona outbreak being a challenge, it has been as a great catalyst that spurred the world of education by encouraging more use of ICT in distance learning activities. Recalling the speech of Indonesian Minister of Education and Culture on May 2, 2020, that this Covid-19 Pandemic has taught humans to be wise and smart, where we can observe the education system which is no longer necessarily limited by space, but can take place ubiquitously and anytime (Kemendikbud, 2020). This is obviously the first time in which most of educational sectors in Indonesia conducted all teaching and learning activities fully through online mode. In fact, it is already the $4^{\text {th }}$ era of Industrial Revolution in which people are supposed to smartly utilize ICT and other technologies to facilitate their daily activities (Daniela, 2019; Keser \& Semerci, 2019). However, there are major challenges in implementing the distance learning model. One of them is that the academic community is not yet accustomed to using a blended and completely online learning system. Studying online while at home is complicated more than can be thought, especially in this period of pandemic(Ch et al., 2020; Guemide \& Maouche, 2020; Saifi et al., 2020; Zai \& Akhunzada, 2020). Many aspects must be reconsidered in order to achieve previous planned objectives, including online learning methods, facilities, teaching-learning strategies, and even services that support online academic activities (Guemide \& Maouche, 2020). Moreover, it is the fact that most individuals among educators and students were not ready enough to easily adapt learning situations in the pandemic (Saifi et al., 2020) including foreign students currently studying in Indonesia.

Full online learning currently being implemented in Indonesia and many other developing countries is something new and sudden for teachers and students alike as well as foreign students. Recently, a study (Ferdiansyah et al., 2020) found that the current policy of full online learning during the pandemic crisis was new to most of foreign students. Another study (Susanto et al., 2020) revealed that online learning during the COVID-19 period affected the emotional geography of international students. Moreover, it was found that the sudden shift of learning modes affected international students to miss many chances and unable to meet their deadline especially graduating on time (Hastowahadi; Setyaningrum \& Pangesti, 2020).

Obviously, the drastic shift from traditional or blended learning to fully learning online affects the psychology of all students in general and international students in particular. Recently, some studies (Azorín, 2020; Raaper \& Brown, 2020) found that the current pandemic crisis affects foreign students' psychological conditions including learning motivation and isolation feelings, while adapting to changes in the learning system. Student engagement is among very vital psychological aspects of students in the learning process. Research (Kahn et al., 2017) shows that there are diverse issues related to student engagement especially in online modes. These issues include low learning retention (Moore, 2014), decreased learning commitment due to frustrations caused by technical difficulties in online contexts (Jaggars, 2014). Moreover, there is a lack of empirical studies on antecedents of student engagement (Osman et al., 2019) in general, and specifically more scarce on causal-effect modeling of student engagement variable(Christenson et al., 2012; Fredricks \& McColskey, 2012; Rumberger \& Rotermund, 2012).

This situation is interesting for researchers to analyze and model foreign students' online learning engagement in the country of study such as Indonesia. Therefore, it's vital to understand 
how and what factors influence foreign students to engage in an online learning process especially during pandemic. So, this study is aimed to review some previous potential literature on student engagement and online learning and to propose a conceptual model of online learning engagement, comprising of possible factors, which affect the engagement of students during and after the pandemic.

\section{Literature Review}

The teaching and learning process is usually carried out at classrooms or through direct interaction without any intermediary media. Though, the advancement in ICT is making the educational process unlimited to time and space. Many educational institutions in the $21^{\text {st }}$ century are implementing education 4.0 whereby most of learning activities are carried out either in blended mode or fully online by the help of ICT (Daniela, 2019; Lorenzo \& Gallon, 2018; Sulistiani, 2019). This is obviously true especially in developed nations due to their improved technological investment. However, in the last few months even developing countries such as Indonesia have implemented a fully online learning process because of a pandemic that has attacked the whole world. Almost all countries have experienced the impact of this pandemic in a way that many have set lockdown status and other anticipations to break the chain of the spread of COVID-19. As a result of these policies, many sectors like economic sector were paralyzed. Apart from the impacted economic sector, education is also one of the sectors that has also experienced the direct impact of this pandemic. As a result of this pandemic educational institutions are still closed particularly in Indonesia with the aim of preventing the spread of COVID-19. Even though schools and universities are closed, the teaching and learning activities don't stop as this is enforced by the Indonesian ministry of education and culture that all educational activities should be carried out through the internet while staying at home.

Online learning activities are carried out over a distance through the internet and e-learning systems and media as well as other supporting tools such as smartphones and computers (Daniela, 2019; Gikas \& Grant, 2013; Lorenzo \& Gallon, 2018; Ziphorah, 2014). There is a bit difference between online learning and conventional learning. In online learning, emphasis is put on the thoroughness and prudence of students in receiving and analyzing learning materials presented online. The concept of online learning has the similar concept as e-learning (Galikyan \& Admiraal, 2019; F. H. Wang, 2017; Wynants \& Dennis, 2018). There are some benefits of online learning that include flexible time management and place to study, for instance learning can be done in the bedroom, living room and so on as well as adjusted times such as morning, afternoon, evening or even at night. It also overcomes problems regarding distance as students do not have to go to schools or campuses. So, there are no restrictions on space and time. Apart from the mentioned advantages, online learning also has its drawbacks and challenges. Some of deficiencies that occur in online learning is that most students find it difficult to focus on studying as the atmospheric situations at home are not so favorable. Limited internet packages and Wi-Fi connections which are the link in online learning as well as interference from several other things are also challenging for studying from home. Online learning also can result to a limited normal interactions between learners and instructors or even between learners themselves (Hadisi \& Muna, 2015). This lack of interaction can slow down the formation of ethics and standards in the teaching-learning process.

Obviously, the challenge brought by Covid-19 pandemic is felt by both local and foreign students, though, the latter group usually face more challenges while studying in the destination country (Le \& McKay, 2018; McGarvey et al., 2015). A number of researches show that students studying abroad face a variety of challenges and require various adaptations, including language, 
culture and education system among others (Brunsting et al., 2018; Li et al., 2018; Luo et al., 2019; Rana et al., 2020; Singh, 2019). Studies from various perspectives regarding the experiences of international students studying in Indonesia are currently still limited (Widiasih et al., 2020). This is true especially in the case of academic experiences of foreign students in Indonesia. Most of recent research on international students studying in Indonesia, focused on aspects of Indonesian language learning experiences. Moreover, many of the previous researchers such as (Hastowahadi; Setyaningrum \& Pangesti, 2020; Nurfaidah et al., 2020; Puspitasari et al., 2020) conducted qualitative studies pertaining to non-academic aspects. Meanwhile, other aspects especially concerning academic systems and learning experiences such as online learning satisfaction and engagement, have not received much attention of researchers.

Based on literature review, so far, there is no study that explains which factors influence international students in Indonesia to engage on online learning especially amidst pandemic period. Therefore, this current study aims to get an overview of online learning engagement and associated influencing factors of learning engagement obtained from previous studies. Consequently, the conceptual model of online learning engagement (MOLE) is proposed based on constructs from previous empirical studies to model the online learning experiences and engagement of international students studying in Indonesia during pandemic.

\section{Methodology}

This study is a qualitative type of research, based on review of literature. The review was done by searching and collecting literature in the form of books and journal articles related to this study's topics. So, the literature sources are obtained through internet search from various databases of scientific databases such as Springer, Science Direct, and Research Gate are among others. Also, google scholar was used for searching literature by implementing specific Boolean strings for filtering important themes by using keywords such as "Covid-19 pandemic", International students, Foreign students, Online learning, Learning engagement, Student engagement, Learning motivation, Learning satisfaction, ICT-Self efficacy, Self-regulated learning, and other terminologies related to factors influencing online learning engagement.

Data obtained from literature sources are described by arranging them according to themes, especially themes related to factors which affect online learning engagement of students, including foreign students in Indonesia. The emphasis is on text analysis from the reviewed body of literature and the analysis technique uses the normative method which examines the clarity of the concepts pertaining student engagement and online learning. Finally, the analysis result is to propose the conceptual model of online learning engagement (MOLE) consisting of potential constructs from previously different empirical studies about online learning, learning engagement and satisfaction, especially constructs which reflect well the context of foreign students.

\section{Findings and Discussion}

\subsection{Learning and Student Engagement}

Student engagement is a student's psychological state both quantitatively and qualitatively, pertaining to behavioral, affective, and cognitive reactions of the educational process in both academic and nonacademic tasks (Christenson et al., 2012; Gibbs \& Poskitt, 2010; Gunuc \& Kuzu, 2015). Learning engagement of a student is a psychological component related to student's feelings of belonging to a campus, accepting institutional values and principles as well as 
participating in academic tasks (Gunuc, 2014; Willms, 2003). Engagement in learning is a manifestation of motivation displayed by students through their cognitive activities, actions, and emotional reactions. It is a persistent, energized, and directed action when having difficulties in learning especially in the interactivity of a student with academic tasks (Handelsman et al., 2005). A study by (Marks, 2000) describes student engagement in education as a socio-psychological phenomenon, particularly the attention given, interest indicated, as well as effort and investment exerted by a learner in the learning process.

Researchers agree that learner engagement is a variable with multiple dimensions. Though, there is no unanimous agreement on the number of its sub-constructs (Christenson et al., 2012; Fredricks \& McColskey, 2012). Some researchers argue that engagement in learning is a multidimensional variable with three dimensions, namely behavioral, cognitive and emotional aspects (Fredricks et al., 2004; Jimerson et al., 2003). These three dimensions have a dynamic interaction within an individual (E. A. Skinner, Kindermann, \& Furrer, 2009; E. A. Skinner, Kindermann, James P. Connell, et al., 2009). Emotional engagement is the first dimension which pertains apprehension of learning norms, interest, a sense of belonging to the institution, as well as reactions to instructors, campus friends and classmates (Gibbs \& Poskitt, 2010). Emotional engagement explains the affective feelings of students in the education process and reaction to individuals in academic interactions, it indicates the phenomena of students if they feel happy, satisfied, enthusiastic, or enjoying, in both academic and nonacademic tasks. Some researchers consider this engagement dimension very significant for fostering students' sense of attachment to their educational institutions (university or school) and influences student's willingness to participate in learning (Fredricks, 2011; Fredricks et al., 2016; Jimerson et al., 2003).

The second dimension is the cognitive engagement, which refers to students' cognitive process in learning and strategies used for academic work, such as liking learning challenges, selfregulated learning, being willing and persistent to learn (Gibbs \& Poskitt, 2010; E. A. Skinner, Kindermann, \& Furrer, 2009). This sub-construct is closely associated with learning motivation and includes thinking and learningtactics both cognitively and in metacognitive way (Fredricks et al., 2004; E. Skinner et al., 2008). This dimension shows student's involvement in the learning process and indicates student's presence both physically and in mentally: including students being attentive, willing to do beyond standards, concentrating, focusing, and participating actively (Connell \& Wellborn, 1991). It means, this sub-construct describes students' efforts required to comprehend and master learning materials. Lastly, the third dimension is the behavioral engagement which leads to actual involvement and participation in both academic and nonacademic activities like obedience to institutional principles and regulations, attending classes, and performing academic tasks (Fredricks \& McColskey, 2012; Jimerson et al., 2003). This component is said to have three sub-dimensions, which are active participation (both inside and outside academic events such as sports and other organized activities), rules compliance, and involvement in learning process like asking or answering questions, paying attention to instructions, and engaging in discussions) (Fredricks et al., 2004). Thus, affective, behavioral, and cognitive dimensions of engagement provide characteristics of student's feelings, actions, thinking (M.-T. Wang \& Eccles, 2013; M.-T. Wang \& Holcombe, 2010).

Increasing student engagement in educational institutions is one of the efforts that educators and stakeholders should do to reduce problems that occur to students. Problems such as low academic achievement, increased levels of learning boredom and increased drop out cases from schools are argued to be resulted from disengagement of students in the educational activities (Fredricks, 2011; Fredricks et al., 2004, 2016). Despite the fact that some students are well engaged 
in the teaching and learning activities, there are also students who are not engaged by being apathetic, chatting with friends, not being excited, not focusing or even sleeping during learning activities (Appleton et al., 2008). Thus, learner's engagement in classroom is very important, because students who feel unmotivated, bored, and uninvolved makes them detached from both the academic and nonacademic aspects of learning process (Appleton et al., 2008; Fredricks, 2011). This is even more critical to be analyzed in online learning context as the direct physical interactions between teachers and students is limited.

Therefore, to increase student success and academic achievement, active student engagement in the learning process is inevitable and very important (Gunuc, 2014; Shernoff \& Schmidt, 2008; M.-T. Wang \& Holcombe, 2010). Students should be actively involved cognitively, emotionally, and behaviorally with the educational process so as to attain skills and knowledge needed for success at the next level of education, complete education, avoid dropouts, high achievement and career (Fredricks et al., 2004; Hirschfield \& Gasper, 2011; Marks, 2000). Nevertheless, student engagement is not an independent variable which makes it so interesting to researchers finding out empirically what possible external factors influence it. Engagement of students in online learning context needs a proper attention and analysis due to some learning limitations associated with it, compared to conventional learning especially the social presence aspect. This is also more important to analyze in the context of foreign students during pandemic. Below is the review of some literature on possible factors which have either indirect or direct effects on student engagement.

\subsection{Factors Affecting Online Learning Engagement}

Student engagement in academic activities is influenced by factors both internal and external to a student. Social support and interaction are external factors that affect achievement, motivation and student involvement in the learning process. Students who get support both morally and materially from the surrounding environment will be more interested in being actively engaged in activities that support their academics. Previous research revealed that there is a direct association between social support (either from parents, instructors, or friends) and student engagement in the learning process (Garcia-Reid, 2007; Hamre \& Pianta, 2001). Students who feel they get social support from their instructors tend to show behavior in accordance with instructors' expectations, tend to be involved, whether from an affective, behavioral and cognitive perspective and reduce the likelihood of these students engaging in disruptive and deviant behavior (Patrick et al., 2007). Other findings indicate that the relationship between the institutional environment which includes emotional support from teachers and friends with student engagement on campus is mediated by individual characteristics as well as psychological factors (M.-T. Wang \& Eccles, 2013). One of the psychological factors is achievement motivation.

Motivation is a process that can determine the level of activity and general direction of human behavior, so that it can influence an individual, arouse and direct the behavior that is displayed by a person (Connell, 1990; Deci \& Ryan, 1985). Thus, students with high achievement motivation are said to be more involved in academic activities than students who have low achievement motivation as argued by the study of (Akpan \& Umobong, 2013). Students with low motivation sometimes do not show maximum effort in their education process. This shows that achievement motivation has an important role in learner's engagement in academic activities. The level of motivation possessed by a learner contributes well to the degree of involvement in academic activities (Appleton et al., 2008; Fredricks et al., 2016; Jacobi, 2018; Sorić et al., 2017). 
Therefore, motivation both intrinsic and extrinsic, is very important and much needed in students for engaging in the learning process.

These three dimensions of learner engagement namely, cognitive, behavioral, and affective, influence student success differently. In the behavioral component, learners with regular class attendance, are attentive to learning, obey school principles, avoiding trouble behaviors like fighting and missing classes, normally attain better scores and have better performance on standardized school assignments and exams (M.-T. Wang \& Eccles, 2013). To increase student engagement in this component, instructors need to provide more support on individual autonomy in an interesting way, providing relevant tasks, and opportunities to decision-making so as to engage in learning and provide more detailed guidance and assignment instructions (M.-T. Wang \& Eccles, 2013; M.-T. Wang \& Holcombe, 2010). Instructors must also be enthusiastic, prepare well, open, discuss student progress, and challenge students' abilities to do things related to their academics (Groves et al., 2015).

In the emotional component, particularly those related to identifying a feeling of belonging to an educational institution, students who have a positive sense of belonging to their institution, where this positive sense of ownership shows a psychological fit for school. They believe the institution (school or university) will facilitate their development needs (M.-T. Wang \& Holcombe, 2010). Students who have a positive orientation towards university or school, feel emotional closeness so they tend to act according to institution rules and feel they have the same goals (Veresova \& Mala, 2016). This indicates that when student perceive that their institution has a good and conducive climate, then they tend to be more engaged with the campus, the elements of campus climate which mean the relationship between faculty members, instructor support, aspects of self-development, clarity of campus rules, application of innovation, as well as the completeness and comfort of the physical environment. Lecturers who are able to create a positive atmosphere and show that the classroom is a safe place can make students more enthusiastic in participating in the learning process, making students emotionally involved in the learning process so that in the end the students will perform better academically. A positive classroom atmosphere is characterized by warm relationships, mutual respect and emotional support, teachers are not only sensitive to academic issues but also social and emotional aspects (Reyes et al., 2012). This applies to both traditional and online learning contexts.

The study of (M.-T. Wang \& Peck, 2013) explains that student engagement on the cognitive component can increase student success in school, students who are cognitively involved have a high achievement index. The cognitive component is said to be closely related to the qualitative extent of cognitive processes and students' learning techniques in academic works, such as being self-regulated, persistence and willing to learn, and liking of learning challenges (Gibbs \& Poskitt, 2010). One aspect of the cognitive component is being self-regulated in doing things. Self-regulation is an individual's ability to manage and control concerned relevant actions, set personal goals and targets, self-evaluate success when achieving those goals, and self-rewarding for obtaining those specified goals (Friedman \& Schustack, 1999, 2016). Increased self-regulation of students can increase student's general success (Fredricks et al., 2004). Improving student selfregulation can be done by means of teachers providing emotional support, discussing with students regarding their work and academic support from peers (Patrick et al., 2007).

Therefore, based on above narrative of previous studies, it can be noted that the influencing factors to student engagement include: student-instructor relations, peer support and interactions, linkage in learning, disposition of a student in self-regulation, motivation and interest in learning, cognitive autonomy, and self-efficacy among others as argued by (Gibbs \& Poskitt, 2010). So, it 
is vital to understand the causal-effect relationships between these factors and student engagement in online learning context especially concerning international students in a foreign country such as Indonesia. So, this study is aimed to propose a theoretical model of online learning engagement in this pandemic period.

\subsection{Proposed Conceptual Model of Online Learning Engagement and Hypotheses}

It is very crucial in the education process to examine the relationship between external factors such as university support, social interactions (between teachers and students; students and learning materials; and among classmates) and internal factors like self-determination and motivation, self-regulated learning, ICTself-efficacy and their effects on student engagement in online learning. This study proposes a conceptual framework for the causal-effect relationship between mentioned factors and student engagement variable. Social interactions can have a direct or indirect relationship with student engagement in online learning as they do in traditional learning. The Figure-1 depicts the proposed conceptual model incorporating factors (variables) influencing student engagement as discussed above.

Based on the conceptual model as depicted in Figure-1, there are four independent variables (Instructor Interactivity, ICTSelf-Efficacy, University Support, and Self-Determination \& Motivation) and four dependent variables (Student-Student Interactions, Student-Material Interaction, Self-Regulated Learning, and Student Engagement). Each relationship (indicated by arrows) between variables (factors) explained in the section above, forms a research hypothesis. These hypotheses are illustrated in the Table-1.

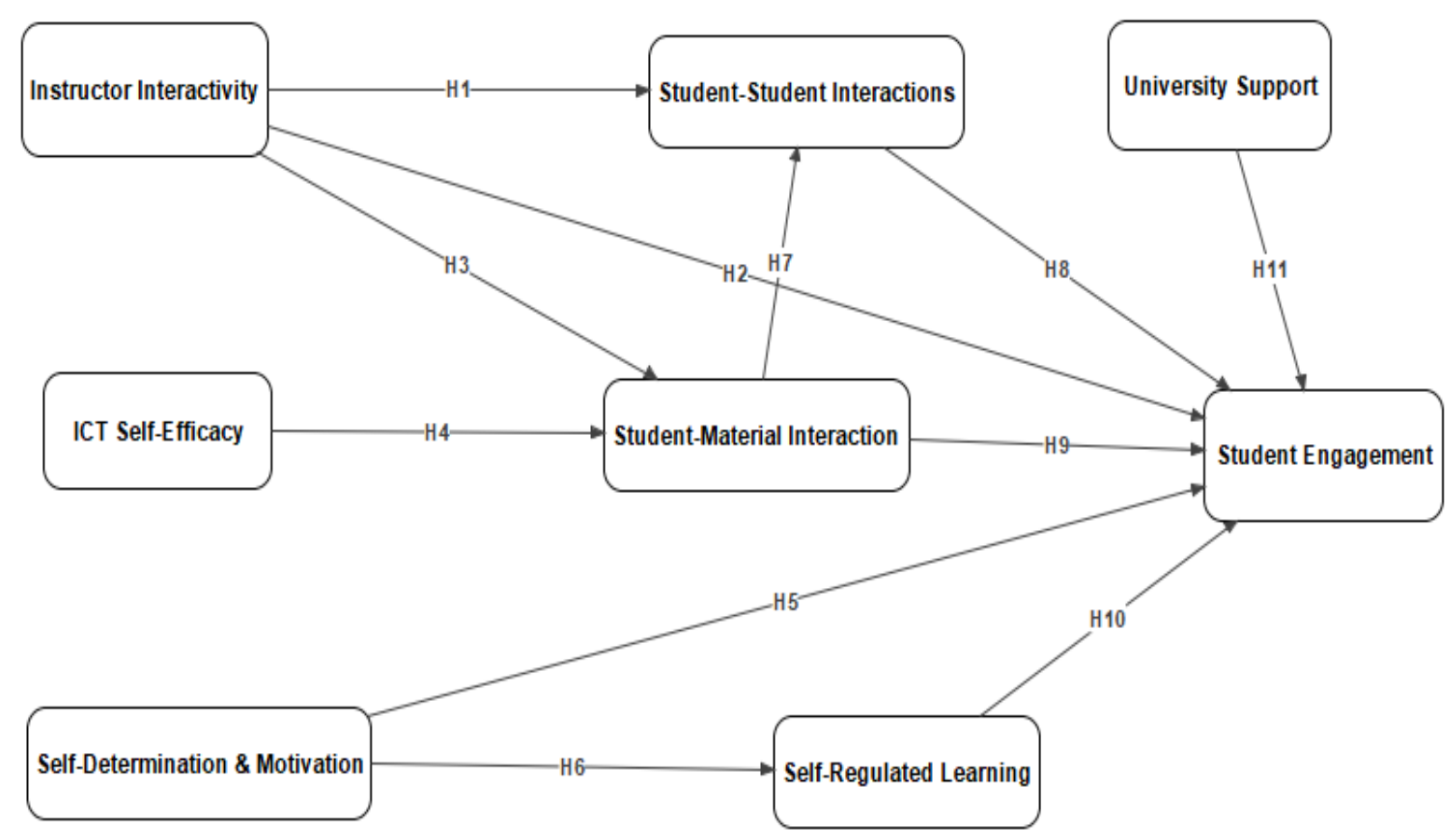

Figure 1. Proposed Conceptual Model of Online Learning Engagement. 
Table 1. Proposed Hypotheses.

\begin{tabular}{ll}
\hline No: & \\
\hline H1 & $\begin{array}{l}\text { Instructor Interactivity will significantly influence student to student } \\
\text { Interactions. }\end{array}$ \\
\hline H2 & $\begin{array}{l}\text { Instructor Interactivity will significantly and directly influence Student } \\
\text { Engagement. }\end{array}$ \\
\hline H3 & $\begin{array}{l}\text { Instructor Interactivity will significantly influence Student to Material } \\
\text { Interaction. }\end{array}$ \\
\hline H4 & $\begin{array}{l}\text { ICT Self-Efficacy will have direct influence on Student to Material } \\
\text { Interaction. }\end{array}$ \\
\hline H5 & $\begin{array}{l}\text { Self-Determination \& Motivation will have positive direct effect on } \\
\text { Student Engagement. }\end{array}$ \\
\hline H6 & $\begin{array}{l}\text { Self-Determination \& Motivation will positively influence Self-Regulated } \\
\text { Learning ability of a student. }\end{array}$ \\
\hline H7 & $\begin{array}{l}\text { Student to Material Interaction will have influence on studentto student } \\
\text { Interaction. }\end{array}$ \\
\hline H8 & $\begin{array}{l}\text { Student to student Interaction will have significant direct influence on } \\
\text { Student Engagement. }\end{array}$ \\
\hline Engagement.
\end{tabular}

\section{Conclusion and Recommendations}

Barriers, solutions and projections in learning using an online system have become an interesting topic especially amid the Covid-19 catastrophe. Based on the condition of prospective educators and learners, conditions for digital system learning can be done. However, this needs readiness and preparation pertaining to socio-psychological conditions so that online learning can be carried out optimally and in an engaging way. This online learning system during pandemic can be used as initial capital for prospective educators and learners in carrying out their learning in the future. For online learning engagement to happen, some factors need to be explored and analyzed to find out their effects on student engagement and put them into consideration during online learning.

From the literature analysis discussed in this article, it can be concluded that there are various factors both internal and external such as social interaction between instructors and 
students, student motivation and other factors have significant influences on student engagement both in online and traditional learning contexts. Thus, the analysis results in this study have implications for the field of educational psychology. In the field of education, it is hoped that the instructors will give attention, advice, help the difficulties faced by students, especially foreign students, and be able to create a good online learning environment so that students feel comfortable, creating positive interactions between students so that students enjoy the teaching and learning process in the online classrooms. Moreover, educational institutions (universities) should give attention, support, accompaniment and assistance to international students' academic and social-economic problems.

This study has its limitation as it isconceptual study based only on literature review which resulted to proposal of conceptual model of online learning engagement. So, empirical research is needed to be conducted in order to validate the proposed model. Thus, future studies should focus on collecting quantitative data of foreign students from Indonesian universities and analyze it, using structural equation model (SEM) technique so as to validate the conceptual model and test the hypotheses proposed in this study. This is so in order to test empirically the causal relationships between proposed factors that can affect student engagement in online learning, either directly or indirectly.

\section{References}

Akpan, I. D., \& Umobong, M. E. (2013). Analysis of Achievement Motivation and Academic Engagement of Students in the Nigerian Classroom. Academic Journal of Interdisciplinary Studies, 2(3), 385-390. https://doi.org/10.5901/ajis.2013.v2n3p385

Appleton, J. J., Christenson, S. L., \& Furlong, M. J. (2008). Student engagement with school: Critical conceptual and methodological issues of the construct. Psychology in the Schools, 45(5), 369-386. https://doi.org/10.1002/pits.20303

Azorín, C. (2020). Beyond COVID-19 supernova. Is another education coming? Journal of Professional Capital and Community, 5(3/4), 381-390. https://doi.org/10.1108/JPCC-052020-0019

Brunsting, N. C., Smith, A. C., \& Zachry, C. E. (2018). An Academic and Cultural Transition Course for International Students: Efficacy and SocioEmotional Outcomes. Journal of International Students, 8(4), 1497-1521. https://doi.org/10.32674/jis.v8i4.213

Ch, S. A., Batool, A., \& Ajmal, M. (2020). Tele-Schooling as Distance Learning Approach in Schools of Pakistan During Pandemic COVID-19. International Journal of Distance Education and E-Learning (IJDEEL), 6(1), 66-82. https://doi.org/https://doi.org/10.36261/ijdeel.v6i1.1422

Christenson, S. L., Wylie, C., \& Reschly, A. L. (2012). Handbook of Research on Student Engagement. In S. L. Christenson, A. L. Reschly, \& C. Wylie (Eds.), Handbook of Research on Student Engagement. Springer US. https://doi.org/10.1007/978-1-4614-2018-7

Connell, J. (1990). Context, self, and action: A motivational analysis of self-system processes across the life span.

Connell, J., \& Wellborn, J. (1991). Competence, autonomy, and relatedness: A motivational 
analysis of self-system processes. In Self processes in development: Minnesota symposium on child psychology. University of Chicago Press.

Daniela, L. (2019). Smart Pedagogy for Technology-Enhanced Learning. In Didactics of Smart Pedagogy (pp. 3-21). Springer International Publishing. https://doi.org/10.1007/978-3-03001551-0_1

Deci, E. L., \& Ryan, R. M. (1985). Intrinsic Motivation and Self-Determination in Human Behavior. Springer US. https://doi.org/10.1007/978-1-4899-2271-7

Ferdiansyah, S., Supiastutik, \& Angin, R. (2020). Thai Students' Experiences of Online Learning at Indonesian Universities in the Time of the COVID-19 Pandemic. Journal of International Students, 10(S3 (2020)), 58-74.

Fredricks, J. A. (2011). Engagement in school and out-of-school contexts: A multidimensional view of engagement. Theory into Practice, 50(4), 327-335. https://doi.org/10.1080/00405841.2011.607401

Fredricks, J. A., Blumenfeld, P. C., \& Paris, A. H. (2004). School engagement: Potential of the concept, state of the evidence. Review of Educational Research, 74(1), 59-109. https://doi.org/10.3102/00346543074001059

Fredricks, J. A., Filsecker, M., \& Lawson, M. A. (2016). Student engagement, context, and adjustment: Addressing definitional, measurement, and methodological issues. Learning and Instruction, 43, 1-4. https://doi.org/10.1016/j.learninstruc.2016.02.002

Fredricks, J. A., \& McColskey, W. (2012). The Measurement of Student Engagement: A Comparative Analysis of Various Methods and Student Self-report Instruments. In Handbook of Research on Student Engagement (pp. 763-782). Springer US. https://doi.org/10.1007/978-1-4614-2018-7_37

Friedman, H. S., \& Schustack, M. W. (1999). Personality: Classic theories and modern research. Allyn and Bacon Boston, MA.

Friedman, H. S., \& Schustack, M. W. (2016). Personality: Classic Theories and Modern Research: Sixth Edition.

Galikyan, I., \& Admiraal, W. (2019). Students' engagement in asynchronous online discussion: The relationship between cognitive presence, learner prominence, and academic performance. Internet and Higher Education, 43(August 2018), 100692. https://doi.org/10.1016/j.iheduc.2019.100692

Garcia-Reid, P. (2007). Examining social capital as a mechanism for improving school engagement among low income hispanic girls. Youth and Society, 39(2), 164-181. https://doi.org/10.1177/0044118X07303263

Gibbs, R., \& Poskitt, J. (2010). Student engagement in the middle years of schooling (year 7-10): A literature review. Report to the Ministry of Education. In Ministry of Education,New Zealand: www.educationcounts.govt.nz/publications 
Gikas, J., \& Grant, M. M. (2013). Mobile computing devices in higher education: Student perspectives on learning with cellphones, smartphones \&amp; social media. The Internet and Higher Education, 19, 18-26. https://doi.org/10.1016/j.iheduc.2013.06.002

Groves, M., Sellars, C., Smith, J., \& Barber, A. (2015). Factors Affecting Student Engagement: A Case Study Examining Two Cohorts of Students Attending a Post-1992 University in the United Kingdom. International Journal of Higher Education, 4(2), 27-37. https://doi.org/10.5430/ijhe.v4n2p27

Guemide, B., \& Maouche, S. (2020). Assessment of Distance Learning in the Algerian Universities during the COVID-19. International Journal of Distance Education and E-Learning (IJDEEL), $6(1)$, $18-46$. http://irigs.iiu.edu.pk:64447/ojs/index.php/IJDEEL/article/view/1420

Gunuc, S. (2014). The relationships between student engagement and their academic achievement. Inernational Journal on New Trends in Education and Their Implications, 5(4), 216-231.

Gunuc, S., \& Kuzu, A. (2015). Student engagement scale: development, reliability and validity. Assessment and Evaluation in Higher Education, 40(4), 587-610. https://doi.org/10.1080/02602938.2014.938019

Hadisi, L., \& Muna, W. (2015). Pengelolaan Teknologi Informasi Dalam Menciptakan Model Inovasi Pembelajaran ( E-learning ). Al-Ta'dib, 8(1), 117-140.

Hamre, B. K., \& Pianta, R. C. (2001). Early teacher-child relationships and the trajectory of children's school outcomes through eighth grade. Child Development, 72(2), 625-638. https://doi.org/10.1111/1467-8624.00301

Handelsman, M. M., Briggs, W. L., Sullivan, N., \& Towler, A. (2005). A Measure of College Student Course Engagement. Journal of Educational Research, 98(3), 184-192. https://doi.org/10.3200/JOER.98.3.184-192

Hastowahadi; Setyaningrum, R. W., \& Pangesti, F. (2020). Forced Remote Learning during the COVID-19 Outbreak: International Students' Stories from a Bahasa Indonesia (the Indonesian Language) for Foreigners Classroom. Journal of International Students, 10 (S3 (2020)), 180-197. https://www.ojed.org/index.php/jis/article/view/3206

Hirschfield, P. J., \& Gasper, J. (2011). The Relationship Between School Engagement and Delinquency in Late Childhood and Early Adolescence. Journal of Youth and Adolescence, 40(1), 3-22. https://doi.org/10.1007/s10964-010-9579-5

Jacobi, L. (2018). What motivates students in the online communication classroom? An exploration of self-determination theory. Journal of Educators Online, 15(2). https://doi.org/10.9743/jeo.2018.15.2.1

Jaggars, S. S. (2014). Choosing Between Online and Face-to-Face Courses : Community College Student Voices. American Journal of Distance Education, 28(1), 27-38. https://doi.org/10.1080/08923647.2014.867697

Jimerson, S. R., Campos, E., \& Greif, J. L. (2003). Toward an Understanding of Definitions and 
Measures of School Engagement and Related Terms. The California School Psychologist, 8(1), 7-27. https://doi.org/10.1007/BF03340893

Kahn, P., Everington, L., Kelm, K., Reid, I., \& Watkins, F. (2017). Understanding student engagement in online learning environments: the role of reflexivity. Educational Technology Research and Development, 65(1), 203-218. https://doi.org/10.1007/s11423-016-9484-z

Kemendikbud. (2020). Pidato Menteri Pendidikan dan Kebudayaan Republik Indonesia dalam Peringatan Hari Pendidikan Nasional Tahun 2020. In Kementerian Pendidikan Dan Kebudayaan Republik Indonesia (Vol. 3, Issue 1). https://www.google.com/url?sa=t\&rct=j\&q=\&esrc=s\&source=web\&cd=\&ved=2ahUKEwj8 qZyOk77wAhWjmOYKHfDuDUEQFjAIegQICBAD\&url=https\%3A\%2F\%2Fwww.kemdi kbud.go.id\%2Fmain\%2Ffiles\%2Fdownload\%2F8aa125b70a29a56\&usg=AOvVaw1_fwhl W3ots1sZE-Sd8xws

Keser, H., \& Semerci, A. (2019). Technology trends, Education 4.0 and beyond. Contemporary Educational Researches Journal, 9(3), 39-49. https://doi.org/10.18844/cerj.v9i3.4269

Le, H., \& McKay, J. (2018). Chinese and Vietnamese international students in Australia. International Journal of Educational Management, 32(7), 1278-1292. https://doi.org/10.1108/IJEM-08-2016-0180

Li, J., Wang, Y., Liu, X., Xu, Y., \& Cui, T. (2018). Academic Adaptation Among International Students from East Asian Countries: A Consensual Qualitative Research. Journal of International Students, 8(1), 194-214. https://doi.org/10.32674/jis.v8i1.160

Lorenzo, N., \& Gallon, R. (2018). Smart pedagogy for smart learning. Didactics of Smart Pedagogy: Smart Pedagogy for Technology Enhanced Learning, 41-69. https://doi.org/10.1007/978-3-030-01551-0_3

Luo, Z., Wu, S., Fang, X., \& Brunsting, N. (2019). International Students' Perceived Language Competence, Domestic Student Support, and Psychological Well-Being at a U.S. University. Journal of International Students, 9(4), 954-971. https://doi.org/10.32674/jis.v0i0.605

Marks, H. M. (2000). Student engagement in instructional activity: Patterns in the elementary, middle, and high school years. American Educational Research Journal, 37(1), 153-184. https://doi.org/10.3102/00028312037001153

McGarvey, A., Brugha, R., Conroy, R. M., Clarke, E., \& Byrne, E. (2015). International students' experience of a western medical school: A mixed methods study exploring the early years in the context of cultural and social adjustment compared to students from the host country. BMC Medical Education, 15(1), 1-13. https://doi.org/10.1186/s12909-015-0394-2

Moore, J. (2014). Effects of online interaction and instructor presence on students' satisfaction and success with online undergraduate public relations courses. Journalism and Mass Communication Educator, 69(3), 271-288. https://doi.org/10.1177/1077695814536398

Nurfaidah, S., Tambunan, A. R. S., Yonata, F., Kurniawati, D., \& Lestariyana, R. P. D. (2020). International Students' Perceptions of Virtual Service Learning Program amidst COVID-19 
Pandemic. Journal of International Students, 10(S3 (2020)), 198-208.

Osman, J., Zainol, Z., Yahaya, R., \& Hudin, N. S. (2019). The Determinants of Student Commitment and Student- Institution Engagement in Malaysian Higher Education Institutions. International Journal of Academic Research in Business and Social Sciences, 9(7), 933-949. https://doi.org/http://dx.doi.org/10.6007/IJARBSS/v9-i7/6192

Patrick, H., Ryan, A. M., \& Kaplan, A. (2007). Early adolescents' perceptions of the classroom social environment, motivational beliefs, and engagement. Journal of Educational Psychology, 99(1), 83-98. https://doi.org/10.1037/0022-0663.99.1.83

Puspitasari, D., Rahayu, W. W., Rohmatunnazilah, \& Suwarno. (2020). Exploring the Feelings of International Students : When We Learn Virtually during the COVID-19 Pandemic. Journal of International Students, 10(S3 (2020)), 142-160.

Raaper, R., \& Brown, C. (2020). The Covid-19 pandemic and the dissolution of the university campus: implications for student support practice. Journal of Professional Capital and Community, 5(3/4), 343-349. https://doi.org/10.1108/JPCC-06-2020-0032

Rana, M., Bhasin, J., \& Mushtaq, S. (2020). Measurement of Cultural Intelligence and Its Impact on Psychological Adaptation of International Students in India. Vision: The Journal of Business Perspective, 24(4), 452-459. https://doi.org/10.1177/0972262920939789

Reyes, M. R., Brackett, M. A., Rivers, S. E., White, M., \& Salovey, P. (2012). Classroom emotional climate, student engagement, and academic achievement. Journal of Educational Psychology, 104(3), 700-712. https://doi.org/10.1037/a0027268

Rumberger, R. W., \& Rotermund, S. (2012). The Relationship Between Engagement and High School Dropout *. In Handbook of Research on Student Engagement (pp. 491-513). Springer Science+Business Media. https://doi.org/10.1007/978-1-4614-2018-7_24

Saifi, I. L., Akhter, N., \& Salamat, L. (2020). Covid-19 Pandemic Shutdown : Challenges of Hei ' s Electronic Support Services in Teacher Education Programs. International Journal of Distance Education and E-Learning (IJDEEL), VI(I), 149-169.

Shernoff, D. J., \& Schmidt, J. A. (2008). Further Evidence of an Engagement-Achievement Paradox Among U.S. High School Students. Journal of Youth and Adolescence, 37(5), 564580. https://doi.org/10.1007/s10964-007-9241-z

Singh, M. K. M. (2019). Academic reading and writing challenges among international EFL master's students in a Malaysian university: The voice of lecturers. Journal of International Students, 9(4), 972-992. https://doi.org/10.32674/jis.v9i3.934

Skinner, E. A., Kindermann, T. A., \& Furrer, C. J. (2009). A Motivational Perspective on Engagement and Disaffection. Educational and Psychological Measurement, 69(3), 493525. https://doi.org/10.1177/0013164408323233

Skinner, E. A., Kindermann, T. A., James P. Connell, A., \& Wellborn, J. G. (2009). Engagement and disaffection as organizational constructs in the dynamics of motivational development. In Handbook of motivation at school (pp. 223-245). Routledge/ Taylor \& Francis Group. 
Skinner, E., Furrer, C., Marchand, G., \& Kindermann, T. (2008). Engagement and Disaffection in the Classroom: Part of a Larger Motivational Dynamic? Journal of Educational Psychology, 100(4), 765-781. https://doi.org/10.1037/a0012840

Sorić, I., Penezić, Z., \& Burić, I. (2017). The Big Five personality traits, goal orientations, and academic achievement. Learning and Individual Differences, 54, 126-134. https://doi.org/10.1016/j.lindif.2017.01.024

Sulistiani, D. (2019). Transformation of Education Institution in Industrial Era 4.0: Modern Management in Islamic Boarding School. Proceeding International Conference on Islamic Education (ICIED), 4(1), 302-310.

Susanto, G., Suparmi, \& Rahayu, E. Y. (2020). The Emotional Geography of International Students in Online Bahasa Indonesia Learning during the COVID-19 Pandemic. Journal of International Students, 10(S3 (2020)), 161-179. https://doi.org/10.32674/jis.v10iS3.3205

Veresova, M., \& Mala, D. (2016). Attitude toward School and Learning and Academic Achievement of Adolescents. The EouropeanProceedings of Social \& Behavioural Science., 870-876. https://doi.org/10.15405/epsbs.2016.11.90

Wang, F. H. (2017). An exploration of online behaviour engagement and achievement in flipped classroom supported by learning management system. Computers and Education, 114, 7991. https://doi.org/10.1016/j.compedu.2017.06.012

Wang, M.-T., \& Eccles, J. S. (2013). School context, achievement motivation, and academic engagement: A longitudinal study of school engagement using a multidimensional perspective. Learning and Instruction, 28, 12-23. https://doi.org/10.1016/j.learninstruc.2013.04.002

Wang, M.-T., \& Holcombe, R. (2010). Adolescents' Perceptions of School Environment, Engagement, and Academic Achievement in Middle School. American Educational Research Journal, 47(3), 633-662. https://doi.org/10.3102/0002831209361209

Wang, M.-T., \& Peck, S. C. (2013). Adolescent educational success and mental health vary across school engagement profiles. Developmental Psychology, 49(7), 1266-1276. https://doi.org/10.1037/a0030028

WHO. (2020a). Q\&A on coronaviruses (COVID-19). In Who (pp. 1-2). https://www.who.int/emergencies/diseases/novel-coronavirus-2019/question-and-answershub/q-a-detail/q-a-coronaviruses

WHO. (2020b). WHO Timeline. WHO Timeline - COVID-19. https://www.who.int/newsroom/detail/27-04-2020-who-timeline---covid-19

Widiasih, R., Hermayanti, Y., \& Ermiati. (2020). International Students ' Experience of Studying at Indonesian Universities : A Systematic Review. Journal of International Students, 10 (S3 (2020)), 24-43. https://doi.org/https://doi.org/10.32674/jis.v10iS(2).2710

Willms, J. D. (2003). Students Engagement at School : a Sense of Belonging and Participation Result From PISA 2000. In Organisation for Economic Co-operation and Development. 
(OECD).

OECD.

http://www.oecd.org/education/school/programmeforinternationalstudentassessmentpisa/33 689437.pdf\%5Cnhttp://scholar.google.com/scholar?hl=en\&btnG=Search\&q=intitle:STUDE $\mathrm{NT}+\mathrm{ENGAGEMENT}+\mathrm{AT}+\mathrm{SCHOOL}+\mathrm{A}+\mathrm{SENSE}+\mathrm{OF}+\mathrm{BELONGING+AND+PARTICIPA}$ TION\#8

World Health Organization. (2020). Digital technology for COVID-19 response. World Health Organization, 1-3. https://www.who.int/news-room/detail/03-04-2020-digital-technologyfor-covid-19-response

Wynants, S., \& Dennis, J. (2018). Professional development in an online context: Opportunities and challenges from the voices of college faculty. Journal of Educators Online, 15(1). https://doi.org/10.9743/JEO2018.15.1.2

Ying, W., Qian, Y., \& Kun, Z. (2020). Drugs supply and pharmaceutical care management practices at a designated hospital during the COVID-19 epidemic. Research in Social and Administrative Pharmacy, April, 0-1. https://doi.org/10.1016/j.sapharm.2020.04.001

Zai, S. A. Y., \& Akhunzada, A. S. (2020). Challenges and Responses of Higher Education institutions to align higher Education with COVID-19 Realities: A Thematic Analysis. International Journal of Distance Education and E-Learning (IJDEEL), VI(I), 109-129.

Ziphorah, R. M. (2014). Information and Communication Technology Integration: Where to Start, Infrastructure or Capacity Building? Procedia - Social and Behavioral Sciences, 116, 36493658. https://doi.org/10.1016/j.sbspro.2014.01.818 